\title{
Do Democratic Principles Constrain the Effectiveness of Elite Cues on Election Rules?
}

\author{
Devin McCarthy
}

August 30, 2020

\begin{abstract}
The public's perception of the fairness of an election rule is an important determinant of popular support for that rule. Thus, the public's fairness principles might act as a constraint on party elite attempts to manipulate election rules for their own electoral benefit. However, if party elites are able to influence what the public considers fair, the effectiveness of this constraint would be limited. This paper posits two possible mechanisms by which this elite influence could function. First, elites could change the public's perception of whether a given fairness principle applies to a given election rule. Second, elites could attempt to directly change which fairness principles people prioritize or endorse. This study tests both mechanisms using survey experiments, finding that elites are able to influence opinion on voting policy issues even when their messages use inapplicable principles. However, elites are unable to directly affect the democratic principles that citizens prioritize.
\end{abstract}




\section{Introduction}

Many worry that the norms and institutions of American democracy are under threat. Party elites are pushing the boundaries of traditionally acceptable conduct in order to secure political wins and defeat the other side. This pattern is particularly noticeable in the context of elections, where parties have frequently changed the rules in ways that seem primarily intended to increase their chances of electoral victory. Some scholars worry that this escalation could ultimately lead to a situation in which the outcomes of American elections are no longer respected by elites or the public (Drutman 2020; Levitsky and Ziblatt 2018; Norris 2017).

One bulwark against such a future is the American public's desire for elections that are fair and legitimate. Most Americans believe that elections are currently free and fair, and place a high importance on free and fair elections (DeSilver 2016; Gibson and Caldeira 2009), though support for democracy has declined somewhat among younger generations (Foa and Mounk 2016) and belief in the integrity of American elections has declined in recent years as conspiracy theories about electoral fraud have taken hold (Norris, Garnett, and Grömping 2020). As long as these beliefs hold, the public has an incentive to impose costs on elites who push elections too far from the norms of free and fair democracy, in the form of electoral punishment (Graham and Svolik 2020) or protest. These costs could deter elites from electoral manipulation that is too blatant or too extreme. However, evidence from countries that have recently experienced democratic backsliding such as Venezuela and Turkey shows that in polarized societies people who are intensely loyal to their party are willing to trade off democratic principles for partisan interest (Svolik 2020).

Given the current high levels of affective polarization in the American mass public (Abramowitz and Webster 2016), there is reason to be concerned about the public's commitment to democracy when partisanship is involved. Polarization provides an opportunity for party elites to influence citizens' opinions on election rules even given the constraints of their democratic principles - that is, their core 
beliefs about what a fair democracy looks like. There are a variety of democratic principles that citizens might care about. Two of the most salient principles in recent years have been voter access and election integrity. While these principles are not mutually exclusive - in fact, both are widely considered to be necessary for free and fair elections - there are some policies that might prioritize one principle over the other. Republicans have promoted policies such as voter ID laws that prioritize election integrity while Democrats have advocated for policies such as automatic voter registration that prioritize voter access, with each side accusing the other of disregarding the importance of their preferred principle.

Self-interested party elites can use citizens' democratic principles for their own ends, employing principled rhetoric in support of policies that would benefit their party in elections. When citizens' principles already align with elites' preferred policies, there is no difficulty. However, when the public's principles run counter to elites' preferred policies, elites might attempt to influence the way citizens think about democratic principles.

If party elites are able to change the democratic principles that people prioritize or justify changes to election rules using principles that are unrelated to those changes, there is little to prevent elites from departing from democratic norms. If, on the other hand, there are limits on party elites' ability to sway public opinion about core fairness principles and how those principles relate to specific policies, there is reason to be more optimistic.

This paper explores the degree to which elites can influence the public's sense of what constitutes a fair election rule, focusing in particular on rules related to voter access such as automatic voter registration, voter ID, vote-by-mail, and making Election Day a holiday. When given a clear choice between the two, the public tends to choose fairness over partisan interest (McCarthy 2020). Therefore, party elites who wish to change public opinion on election reform outside of the narrow set of their most committed supporters must rationalize their favored policies according to democratic principles. If 
mere endorsement by these leaders is insufficient to induce public support, they have no choice but to attempt to change how the public perceives democratic principles.

There are two mechanisms by which elites could accomplish such a change. First, elites could change the public's perception of whether a given fairness principle matches up with a given election rule; that is, party elites could induce citizens to associate a fairness principle with an election reform for which they would like to increase support. Second, elites could attempt to directly affect which fairness principles people prioritize or endorse, with the expectation that this change will cause the public to support the election rules associated with those principles. Alternatively, it could be the case that principles are unnecessary in elite messaging; elites could move opinion with a simple endorsement of the policy they want or by embracing partisan interest as sufficient reason to support a policy.

I assess these possibilities using three survey-embedded experiments, testing each in turn. The first study tests how citizens respond to party leaders explicitly saying that they want certain election reform for reasons of electoral benefit to determine if elite cues need to involve fairness principles at all. The second study tests whether the applicability of a principle to a policy matters for the effectiveness of elite cues. The final study tests whether elites are able to directly influence citizen's beliefs about what is most important for a fair democracy. The experiments employ treatments that give respondents messages from party elites about specific election reforms or on principles of voter access more generally and then ask respondents about their support for those reforms and principles.

In the first study, I find that elites are not able to increase support for their preferred policy simply by stating that it will help their party win elections. People are averse to hearing that a politician endorses an election rule for self-interested reasons. Such statements cause respondents to be significantly less likely to endorse the policy when the politician was from the opposing party and nonsignificantly less likely to support the policy when the politician was from their own party. 
Study 2 finds strong evidence that party elites are able to influence opinion on election policy regardless of the principle that they use to explain their position. Using an inapplicable principle or appealing to negative partisanship are equally as effective in persuading partisans as using an applicable principle. These results suggest that citizen opinion on low-profile election policy issues is easily influenced by party elites and that elite messaging does not need to be coherent in order to be effective.

In the final study, citizens appear resistant to elite attempts to directly influence their democratic principles. Messages from party elites endorsing a particular principle related to determining election rules do not cause partisans to be more likely to prioritize that principle. Critically, citizens are no more likely to endorse extreme principles such as "only citizens who can speak and read English should be able to vote" after being told those principles were endorsed by their party leaders. These results are more encouraging, suggesting that while citizens may be influenced on low-salience policy issues, swaying citizens from their core democratic principles is not so easily accomplished.

\section{Democratic Principles, Political Elites, and the Mass Public}

One of the primary objectives of party elites is to win elections for their party, and one of the best ways to ensure victory is to change the election rules so that they benefit the party. There is little doubt that party elites regularly engage in such manipulation. Across a variety of contexts, elites have been observed changing the rules of political institutions for their own benefit (Binder 2006; Boix 1999; Hersh 2015; Riker 1982).

Whether partisans in the mass public are similarly eager to change election rules purely for partisan benefit is a more complicated question. There is evidence that the public is motivated by strategic interest on issues ranging from the Electoral College to redistricting to voter access (Aldrich, Reifler, and Munger 2014; Biggers 2018; Kane 2017; Karp and Tolbert 2010; Tolbert, Smith, and Green 2009; Woon 2007). Citizens may also engage in partisan motivated reasoning on election issues; for instance, partisans are significantly more likely to perceive an election as having been fraudulent if a 
candidate from the other party won (Beaulieu 2014). However, there is also a long literature demonstrating that the fairness of procedures is an important motivation for public opinion on procedural issues, including democratic procedures (Lind and Tyler 1988; Sunshine and Tyler 2003; Tyler 2013). Pure partisan interest may motivate some citizens in certain cases, but on average citizens are no more likely to support a voting reform after learning it will improve their party's electoral fortunes (McCarthy 2019).

Therefore, there are likely to be many cases in which party elites want to change election rules for their own benefit but find citizens - even their own party's supporters - to be unenthusiastic. In such cases, elites might attempt to persuade the public to follow their policy preferences. There is longstanding evidence that cues from party elites have a substantial impact on public opinion (Lenz 2012; Zaller and Feldman 1992). Partisans are especially likely to follow elite cues in polarized contexts (Druckman, Peterson, and Slothuus 2013). As election reform is a polarized policy area, there is good reason to think that elite cues on election-related issues would be effective.

However, partisan cues are not all-powerful, and are less effective in certain circumstances. When citizens have significant information about policies, they are just as likely to use that information as elite cues when coming to their opinion about the policy (Bullock 2011). Citizens care more about learning which social group a policy benefits than learning which elites endorsed the policy (Nicholson 2011). Partisans are more likely to change their opinion in response to a cue from the opposite party than one from their own party (Goren, Federico, and Kittilson 2009; Nicholson 2012; Yeyati, Moscovich, and Abuin 2020). Thus, we would expect elite cues to have the biggest effect on low-salience election issues and have a larger impact on the views of out-partisans than in-partisans. The impact of elite cues may be blunted when the policy in question would have a direct effect on the respondent's social group. For instance, elite cues may have less of an impact on support for making Election Day a holiday among voters who typically work long hours on Election Day and have trouble finding the time to vote. 
For many election policy issues, citizens might form their opinions based on their fundamental beliefs about what is important in a democracy. While it may be relatively easy for politicians to influence public opinion on policy issues, influencing these core beliefs is a more challenging task. Citizens have some underlying political principles (typically referred to in political psychology literature as political values) that tend to be relatively stable and are resistant to short-term political events (Feldman 1988). Values also constrain policy preferences (McCann 1997), meaning that it might be necessary for politicians to directly change principles in the mass public in order to achieve public support for certain policy goals.

That said, while values are more stable than policy opinions, they are less stable than partisan identity and are constrained by partisan identity (Goren 2005). As a result, party identity can gradually cause peoples' values to change in accordance with the values prioritized by the party. Values are strongly associated with ideology and partisanship but not associated with economic class (Ciuk, Lupton, and Thornton 2018), suggesting that party elites may be able to shape values over a long period of time.

The literature on political values primarily studies core political values, such as equal opportunity, limited government, traditional family values, and moral tolerance. This paper does not study those "core" values, but rather values specifically relating to democracy. While democratic values and principles are widely-used concepts in political science, they are rarely well-defined. ${ }^{1}$ For example, "democratic values" is often operationalized with a survey item asking whether someone supports or opposes democracy in general (Besley and Persson 2019). Another common approach is to ask the degree to which respondents endorse a series of principles that the researcher views as aligned with a free and fair liberal democracy (Caldeira and Gibson 1992; Bright Line Watch 2017). In these items, people are either supportive of democratic values or opposed to them. When these sorts of principles

\footnotetext{
${ }^{1}$ The terms democratic values and democratic principles are used interchangeably in this paper since they are not clearly distinguished in the literature, but I will primarily use principles when not referring to another paper.
} 
are used in candidate choice experiments as a principle endorsed or opposed by a candidate (Carey et al. 2018; Graham and Svolik 2020), the candidate is intended to be either supportive or opposed to democratic values.

The limitation of this approach is that while there are some principles that it is reasonable to consider more objectively "democratic," most political discourse on democracy deals with policies in which there are tradeoffs among different democratic principles. Most political contests do not involve one candidate or party endorsing liberal democratic principles and the other opposing them. Instead, politicians of both sides seek to couch their preferred policies in terms of some democratic principle. This paper avoids normative judgements about which principles related to elections are "democratic," instead constructing a range of possible principles people might have related to issues of voter access and election integrity. These principles share characteristics with the standard definition of values outlined by Schwartz (1994): They are abstract beliefs, can be rank-ordered in terms of importance, and, while they are confined to the particular policy sphere of election rules, they transcend any individual election policy. Thus, there is good reason to expect these democratic principles to behave similarly to core values.

The main takeaway of the literature on elite cues is that party elites are consistently able to influence public opinion on public policy issues but are less able to shift the relative importance the public places on political values. In the following studies, I test whether that general framework applies to the specific case of electoral rule change, where the ability of elites to sway peoples' positions and core principles is particularly important for the health of democracy.

\section{Study 1: When Elites Admit to Partisan Motivation}

Before testing elites' ability to influence democratic principles in the mass public, I first test whether elites need to use principles to justify their election reform positions at all. If the public is sufficiently polarized, partisan interest alone could be sufficient to move opinion. This experiment tests 
whether people are still influenced by elite cues when those cues explicitly justify support for a policy on the grounds that it would benefit the party. If such cues were effective, it would allow elites greater latitude to pursue electoral manipulation without worry that their partisans would punish them for doing so.

While politicians do not typically state in public that they support election reform in order to help their party, there have been several instances in which party elites have been caught on tape making these types of statements. I refer to these instances as "hot mics," although some of them resulted from leaked documents or politicians making ill-advised statements in public speeches or interviews. There have been several notable recent examples of this, most commonly Republicans who slip up and say that the passage of a voter ID law will help them win elections (Wines 2016).

For example, when Pennsylvania Republican House leader Mike Turzai was listing the legislature's accomplishments during the 2012 campaign, he said "voter ID, which is going to allow Governor Romney to win the state of Pennsylvania, done." In 2016, Wisconsin Rep. Glenn Grothman said of the state's new voter ID law that "I think photo ID is going to make a little bit of a difference as well" in allowing Republicans to defeat Hillary Clinton. These quotes imply that the reason voter ID laws will help Republicans win is by preventing Democratic voter fraud. However, there is a substantive difference between the standard GOP message that voter ID would preserve election integrity and these messages that highlight the law's partisan benefits.

In this study, I use examples of "hot mics" as treatments to test how voters respond to elite admissions of prioritizing partisan interest over principle. In the experiment, a control group is given some basic information about two laws - automatic voter registration and voter ID laws - and asked their opinion of those laws. A treatment group is additionally told that one of the laws is controversial because of its possible partisan effects, then given a "hot mic" example. This experiment presents a clear test between two competing theories of public opinion on election laws: either opinion is primarily 
driven by party elite cues and partisan electoral consequences, or voters are significantly constrained by concerns of fairness. Under both theories, respondents of the opposite party of the "hot mic" party should be less supportive of the policy after seeing the treatment. If the former theory is true, the treatment should increase support for the law among like-partisans, who will only see reinforcement that the law is supported by their party elites and will help their party in elections. If the latter theory is true, however, support for the law should stay the same or even decrease among like-partisans, who will not be persuaded by a nakedly partisan rationale for supporting the law.

The experiment has two treatment groups: one in which respondents are first given a "hot mic" example for voter ID laws and subsequently given a similar example for automatic registration, and a second in which the election reforms are reversed. This allows me to test a secondary hypothesis: that people presented with evidence of the opposite party's behaving "unfairly" will be more likely to tolerate partisan behavior in their own party.

\section{Data and Methodology}

Respondents for this study were recruited in the Duke University module of the 2018 Cooperative Congressional Election Survey, administered by YouGov. This survey was given to 1000 respondents. It was non-probability and internet-based but was designed to be representative of all U.S. adults.

The experiment randomly assigns respondents to one of three experimental groups: the control group, a group that is shown the automatic registration treatment first, and a group that is shown the voter ID treatment first. The full text of these treatments is shown below. For the group shown the voter ID treatment first, the text of Question 2 is simply reversed with the text of Question 1, with minor adjustments to the text. 
Control:

- Question 1: Automatic voter registration laws automatically register a citizen to vote any time they interact with a government agency.

- Question 2: Voter ID laws require citizens to show a photo identification at the ballot box in order to cast a vote.

Treatment:

- Question 1: Automatic registration is an election reform that would automatically register a citizen to vote any time they interact with a government agency. The reform has proven controversial, in part because some believe the law might help Democrats in elections. One prominent Democrat in Oregon was recently caught on tape at a fundraiser saying, "We passed automatic registration this year, which is going to help Democrats win the midterm elections all across Oregon."

- Question 2: Voter ID laws require citizens to show a photo identification at the ballot box in order to cast a vote. The reform is also controversial, in this case because some believe the law might help Republicans in elections. A prominent Republican was similarly caught on tape saying, "We're going to beat the Democrats this November, and the new voter ID laws are going to help."

Following each treatment or control text, respondents are asked if they favor or oppose voter ID/automatic registration. In addition to this question, respondents were also asked standard demographic questions including age, gender, education, and race.

This study uses OLS regression to estimate the effect of the treatments on support for the two voting reforms. It includes the four demographic variables as controls. The same model is run on both the Democratic and Republican respondents. 


\section{Results}

Figure 1 shows the results of the hot mic experiment. As expected, there is a clear partisan difference in how respondents were affected by the treatments. Also as expected, both Democrats and Republicans were significantly less likely to support a policy when told that the other party supported the policy primarily for reasons of electoral interest. Republicans told that Democrats admitted passing automatic registration in order to benefit Democrats in elections rated automatic registration 0.63 points lower on a five-point scale. Democrats told that Republicans admitted passing voter ID laws to help them win elections rated voter ID 0.56 points lower on a five-point scale.

However, even partisans who heard a message about a leader of their own party supporting an election reform for partisan reasons were less likely to support that reform in all cases, though those differences were not significant. There is no evidence that partisans are following the cues of their party leaders in 'hot mic' cases.

Seeing an example of the opposite party admitting to changing election rules for the sake of partisan interest does not make partisans willing to follow their own party elites in prioritizing partisan interest. However, the order in which respondents see the treatments does seem to have some effect. Republicans who first saw an example of Democrats admitting to manipulation were significantly less supportive of automatic registration than Republicans who first saw their own party admitting to manipulation. Similarly, Democrats who first saw Republicans admitting to manipulation were less likely to support voter ID than those who had been informed that Democrats engage in similar behavior prior to the question, though this difference was not significant. These results suggest that seeing a case of one's own party prioritizing partisanship blunts the negative impact of seeing the other side doing the same. 

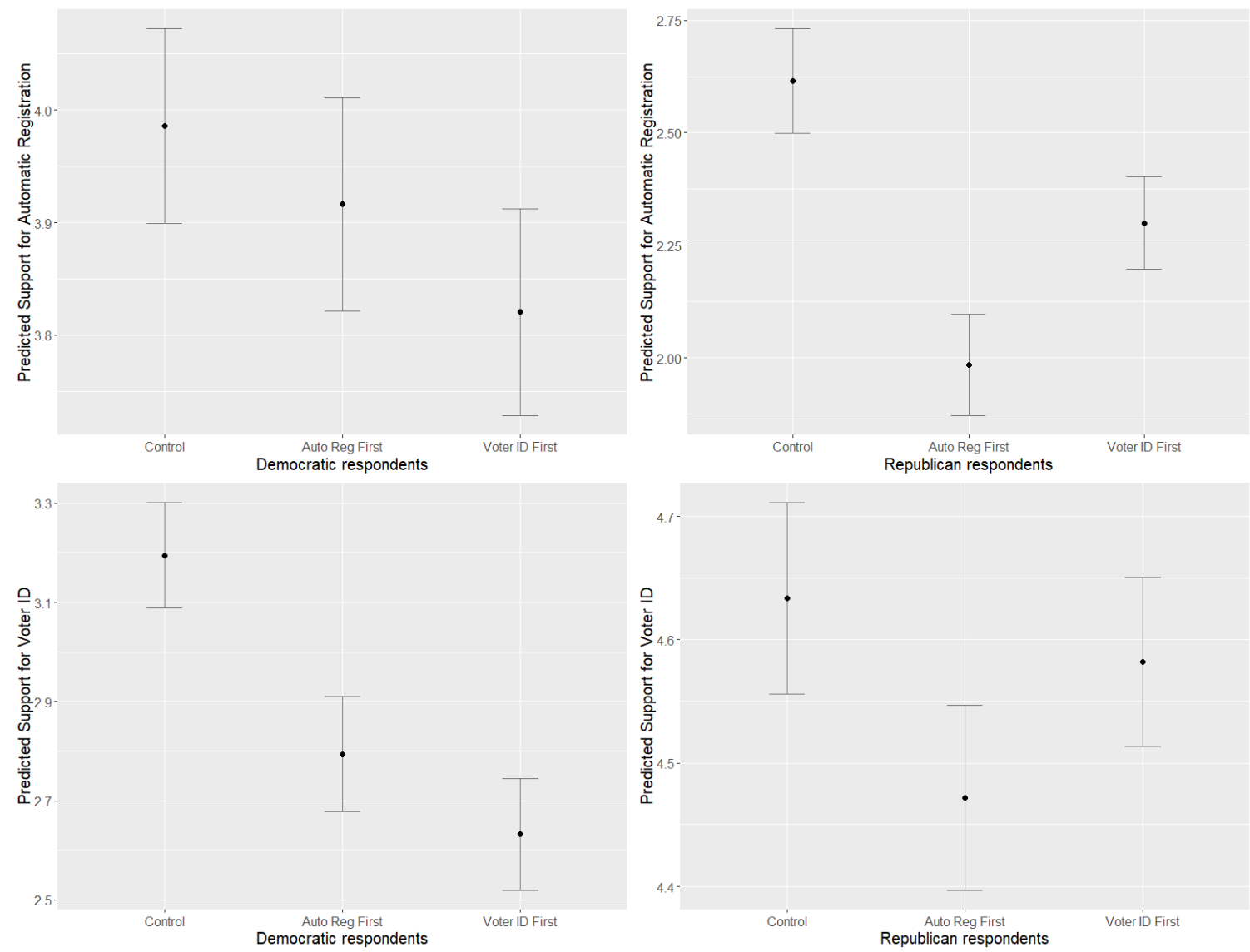

Figure 1: Predicted probability of supporting automatic registration and voter ID laws among Republicans and Democrats, by treatment group

\section{Study 2: Principle-Policy Congruence}

The previous study showed that partisan interest alone is not a sufficient justification for an effective elite cue on election reform. Study 2 tests whether the relevance of normative justifications used by party leaders matters for the effectiveness of their messaging. Party elites may have a policy that they wish to enact because it would benefit their party in elections but lack an appropriate normative justification that fits with their party's ideology. In such a situation, they might simply use an unrelated principle to justify their support for the policy. A similar approach might be used to oppose a policy proposed by the opposing party that does not have an appealing principle-based counterargument. 
While politicians rarely use completely nonsensical justifications, they do often attempt to stretch the boundaries of the link between policies and values. For instance, a common talking point used by Republicans advocating for voter ID laws is that there are many dead people still on voter rolls (Ura 2019). While this claim may be true in some instances, it is likely an attempt to conflate a value that does not directly apply to voter ID laws (maintaining accurate government records) with one that does (preventing ineligible people from voting). Because there is little evidence that voter ID laws would reduce voter fraud (Levitt 2014), Republican leaders are forced to justify their support for the policy with less-applicable evidence and values. To test whether these boundary stretches are effective, this study will use an extreme case: one in which the justification used by the party elites is completely inapplicable to the policy in question.

There are psychological reasons why we might expect the applicability of a policy justification to matter. The applicability of a construct to a particular stimulus affects whether that construct will be used (Higgins 1996). While the most commonly discussed factor in whether a consideration is used in opinion formation is the accessibility of the consideration, applicability is a moderating variable in that relationship (Althaus and Kim 2006; Nelson, Oxley, and Clawson 1997). Issue frames that use applicable considerations tend to be more effective than those that do not (Chong and Druckman 2007). Even if the principle of voter fraud is primed and accessible, for instance, people might not apply it to a given policy if they do not consider the policy to be related to voter fraud.

However, it is possible that the particular context of election rules with known partisan effects may lessen the importance of applicability. We know that motivated reasoning is particularly likely in polarized contexts (Druckman, Peterson, and Slothuus 2013). Partisans may be motivated by the prospect of electoral benefit to accept any justification that elites provide, even if the justification would not normally register as applicable absent elite cues. Partisans may simply wish to be reassured by their 
party elites that there is some principled reason to take the election rule position that most benefits their party.

In order to test whether a strategy of using non-applicable principles to justify policy positions would be effective, this study randomly assigns respondents to receive a party elite message opposing a particular voter access reform using a principle justification that either corresponds to or does not correspond to the reform. If party elites are constrained in their ability to influence public opinion by the coherence of their principle justifications, we would expect justifying opposition to a policy with an applicable principle to significantly decrease support among like-partisans. We would expect a justification using an inapplicable principle to have no effect.

The treatments used in this study were inspired by a notable recent party elite message on election reform: an op-ed written by Republican Senate Majority Leader Mitch McConnell in opposition to the H.R. 1 omnibus election reform bill that was later passed by the Democratic House (McConnell 2019). Among other objections, McConnell justifies his opposition to the Democrats' proposal of making Election Day a holiday by arguing that the result of this policy would be "extra taxpayer-funded vacation for bureaucrats to hover around while Americans cast their ballots." He also includes the more common Republican concern that Democratic efforts to expand voter access increase the risk of voter fraud. Finally, his primary argument against the bill, made clear in the headline "Behold the Democrat Protection Act," is that the bill is first and foremost an effort by Democrats to manipulate the rules in order to win re-election.

Each of McConnell's justifications is tested in a different treatment in this experiment. Respondents are asked for their opinion on either making Election Day a holiday or adopting universal vote-by-mail. Before this, respondents in three treatment groups are given a message from Republicans expressing their opposition to whichever of the two policies respondents are assigned to, using one of the three justifications employed by McConnell in his op-ed. Because treatment groups are randomized, 
some respondents will see a Republican principle justification that corresponds to their assigned policy, and some will see a justification that corresponds to the policy they were not assigned. For example, some respondents see a message saying that Republicans oppose making Election Day a holiday because doing so would increase voter fraud, instead of McConnell's argument that making Election Day a holiday would create taxpayer-funded vacation time for bureaucrats.

In addition to these Republican messages, respondents in the treatment groups are also given information from "scholars" about the expected impacts of the policy: namely, that it would increase voter turnout overall and among Democrats in particular. One group is only given the information from scholars, without any party messaging. This information is included to distinguish any treatment effects found from pure partisan interest. Respondents could infer from a party leader' opposition to a voting policy that the policy would hurt their party and oppose it on those grounds. This design allows me to disentangle the effects of partisan interest and elite cues.

This study is one-sided in partisan terms, in that all party elite messages are coming from Republicans. The treatments' effects on Democrats show how Democrats react to Republican opposition to liberal voting policies. The decision to keep the experiment one-sided was made partly to keep the experiment a manageable size, as the sample is already randomly split into ten groups. Furthermore, the issue of voter access itself is somewhat asymmetric. With the exception of voter ID laws, there are few voting policy reforms being regularly promoted by Republicans; most of their efforts are directed against Democratic attempts to liberalize voting laws. Finally, there is no theoretical reason to think that Democrats and Republicans would respond differently to these treatments. Recent experiments have found no significant difference between Democrats and Republicans in their degree of partisan bias when evaluating new information (Ditto et al. 2019). 


\section{Data and Methodology}

The study recruited 2,559 American adults to participate in a non-probability internet-based survey through the Lucid Fulcrum exchange. The survey was conducted from November 14-18, 2019. The study uses a $2 \times 5$ experimental design. First, respondents were randomly assigned to provide their opinion on one of two policies: vote-by-mail or making Election Day a holiday. Next, respondents were randomly assigned to one of five experimental groups. These groups consist of one control group and four treatment groups. The first treatment group only provides respondents with information suggesting that the policy would increase turnout primarily among Democrats. The other three treatments include that information as well as a message from Republican leaders opposing the policy. The full wording of these treatments is shown below.

- Group 1: In recent years, reformers have proposed [making Election Day a federal holiday/allowing all voters to vote by mail] in order to make voting easier.

- Group 2: In recent years, reformers have proposed [making Election Day a federal holiday/allowing all voters to vote by mail] in order to make voting easier. Some scholars have found that the reform increases overall voter turnout, primarily among Democrats.

- Group 3: [All text from Group 2] Republican leaders have opposed this policy, arguing that it is an attempt by Democrats to change the rules to benefit their own party in elections.

- Group 4: [All text from Group 2] Republican leaders have opposed this policy, arguing that it would simply create extra taxpayer-funded vacation time for bureaucrats.

- Group 5: [All text from Group 2] Republican leaders have opposed this policy, arguing that it would increase voter fraud.

After the treatment, respondents are asked whether they favor or oppose the policy. This item is used as the dependent variable in the analysis of this experiment. 
Before the experimental treatment, respondents were asked questions measuring the strength of their commitment to multiparty democracy (Gibson and Nelson 2015), negative partisanship (Abramowitz and Webster 2016), and standard demographic questions including gender, age, and race. These five variables are included in all the models in this analysis, along with a variable indicating the respondent's treatment group. The analysis runs four OLS models using these variables, one for each party/policy combination.

\section{Results}

Before testing whether the applicability of principle justifications affects the effectiveness of elite cues, I must first determine whether voters in fact associate different principles with different policies. This was tested in a separate pretest survey, also conducted through the Lucid Fulcrum exchange, in which respondents were asked about the effects of EDH and VBM. These questions asked to what degree respondents thought the two policies would benefit Democrats in elections, would increase voter fraud, and would create extra taxpayer-funded time off for bureaucrats. The results of these questions are shown in Table 1 below.

Table 1: Perceived applicability of principle-relevant outcomes to making Election Day a holiday and vote-by-mail. Original question used a 5-point scale, which is collapsed to a 3-point scale in this table.

\begin{tabular}{lcccccc}
\hline \multicolumn{3}{c}{ Election Day Holiday } & \multicolumn{3}{c}{ Vote-By-Mail } \\
\hline Outcome & $\begin{array}{l}\text { Benefits } \\
\text { Dems }\end{array}$ & Bureaucrats & Fraud & $\begin{array}{l}\text { Benefits } \\
\text { Dems }\end{array}$ & Bureaucrats & Fraud \\
\hline Agree & $36 \%$ & $51 \%$ & $25 \%$ & $35 \%$ & $29 \%$ & $52 \%$ \\
Neither & $38 \%$ & $31 \%$ & $27 \%$ & $41 \%$ & $35 \%$ & $25 \%$ \\
Disagree & $25 \%$ & $18 \%$ & $47 \%$ & $25 \%$ & $36 \%$ & $24 \%$ \\
\hline
\end{tabular}

As expected, most respondents think making Election Day a holiday would create extra taxpayer-funded time for bureaucrats and a plurality of people think it would not lead to more voter 
fraud. The reverse is true for vote-by-mail: a majority think it causes voter fraud and a plurality disagrees that it would create extra taxpayer-funded time for bureaucrats. For both policies respondents are ambivalent about whether it helps Democrats, though more respondents agree with the statement than disagree. These results suggest that the treatments in this study are in fact testing whether an elite cue with an inapplicable principle is less effective than a cue with an applicable principle.

The results of the experiment are shown in Figure 2. In three of the four policy-party combinations, there is a clear and consistent effect. Republicans who were given messages from leaders opposing making Election Day a holiday were all less likely to support the policy. This effect was significant at the $p=.05$ level for the message arguing that the policy is a Democratic attempt to win elections. It was marginally significant for the two principle-based arguments, but the differences among these three treatments are trivial, ranging from -0.39 to -0.50 on a 5-point scale.

Among Democrats, for both policies the Republican message that the policy was a self-serving Democratic ploy significantly increased support. In both cases, this increase was about 0.5 on a 5-point scale. The Republican principle-based justifications also increased Democratic support in each case. For $\mathrm{EDH}$, the effect of the voter fraud argument was significant (effect size of 0.35 ) and the effect of the bureaucrat argument was marginally significant (effect size of 0.29). For VBM, neither effect was significant. These relatively strong results for Democrats are in accordance with previous literature showing that party cues matter more for out-partisans than in-partisans. The only case in which there were no significant treatment effects was Republicans asked about vote-by-mail.

Overall, there is no evidence that the applicability of a principle justification to a policy in an elite message affected voters' response to that message. In fact, in none of the four cases was the estimated support for the policies significantly different between the group receiving principle justifications appropriate for making Election Day a holiday and the group receiving a justification appropriate for vote-by-mail. 
In none of the four cases did the treatment simply informing respondents that the policy might benefit Democrats in elections have a significant effect on support for the policy, though the effect was in the expected direction in three of four cases and marginally significant in one. Partisan interest alone was not enough to significantly move opinion; only when combined with a party leader endorsement did opinion shift. Nonetheless, there was only one case in which the combination of party message and partisan interest information was significantly different from just the party interest information.
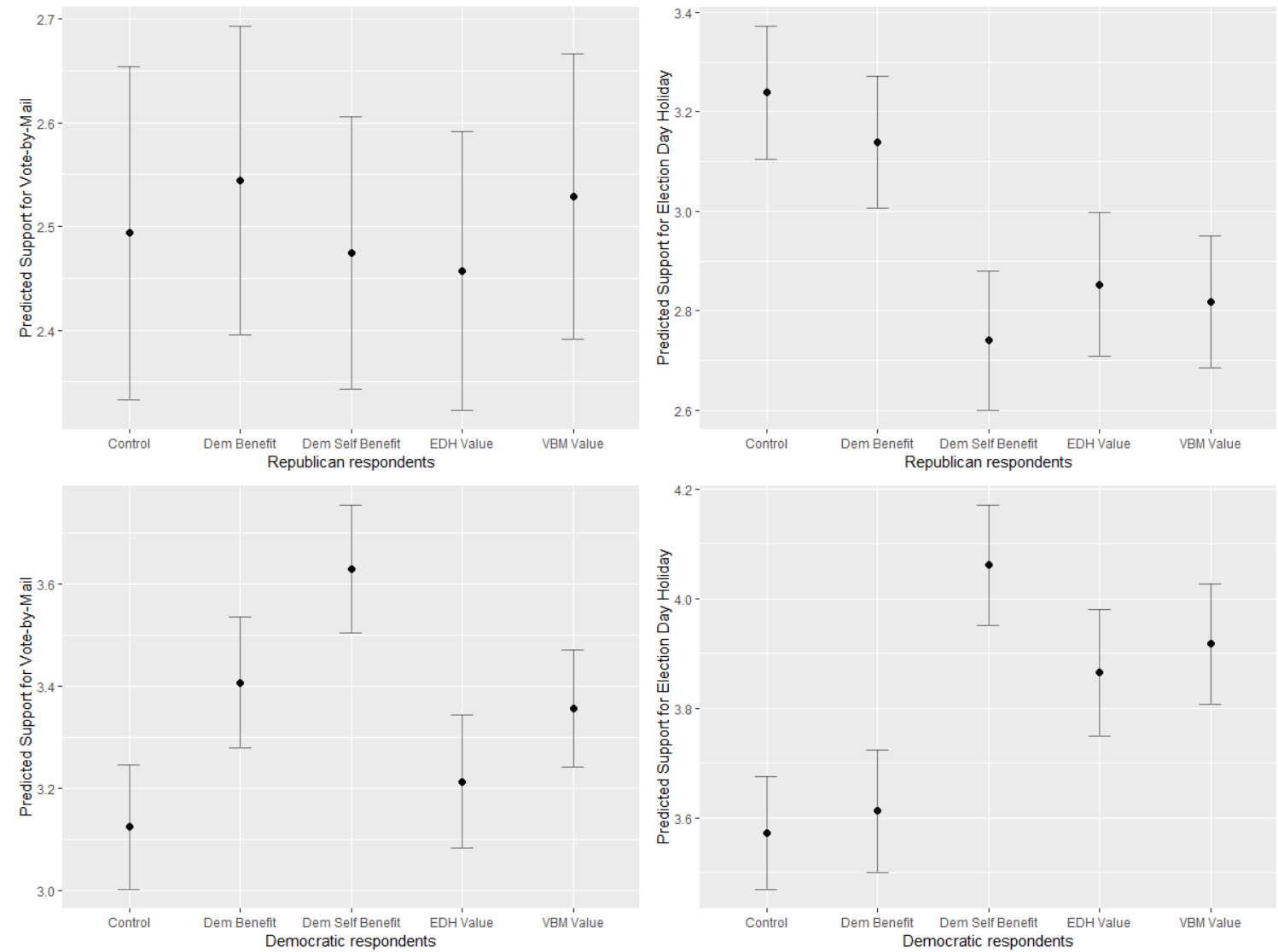

Figure 2: Predicted support for vote-by-mail and making Election Day a holiday across five treatment groups, among Democratic and Republican respondents. 


\section{Study 3: Directly Manipulating Fairness Principles}

Another method that elites might use to affect opinion about election reform is to directly influence the principles that citizens prioritize when thinking about elections. The effectiveness of this method is tested in this third study.

To examine this question, I first construct a set of principles that citizens might hold relating to how elections are run. For the sake of simplicity, I confine those principles to issues relating to voter access. I use six principles, three that are more likely to be associated with a liberal perspective and three that are more conservative in nature. Of the three on each side, one principle is intended to be a moderate principle that most Americans would agree with, one is intended to be a more ideological principle that only strong partisans would prioritize, and one is intended to be an extreme principle that is outside the realm of common political discourse in the U.S. This structure allows a test not only of whether party elites are able to influence citizens' principles but also whether they are able to push people to consider more extreme principles than they otherwise would.

Respondents in this study see two messages, one from leaders of each party. These messages do not endorse particular policies, but instead endorse a principle that would govern all election reform efforts. The principles in these messages each correspond to one of the set of principles that respondents will later be asked to rank. If party elites are, in fact, able to influence the democratic principles that their partisans care about, we would expect to see respondents who see their party elites endorsing a particular principle be more likely to prioritize that principle themselves.

\section{Data and Methodology:}

In this third study, 1301 American adults were recruited to participate in a non-probability internet-based survey, again through the Lucid Fulcrum exchange. Of these, 978 respondents were retained after those who failed to answer items used as dependent or independent variables were eliminated. The survey was conducted from December 13-17, 2019. 
This study uses a $3 \times 3$ experimental design, in which all respondents are randomly assigned to receive one of three Republican messages and one of three Democratic messages, aside from a control group that does not receive any message. The messages are each an argument that America's election system should be reformed based on a certain principle. These principles range from the moderate (for Democrats, "expanding access to the ballot box") to the extreme ("expanding voting rights to all American residents"). These messages are shown in full below. All non-control respondents are shown the control text before being shown one Republican and one Democratic message.

Control: Voting reform promises to be a hot topic during the 2020 elections. Republican messages:

- GOP Message 1 (Moderate): Republican leaders have argued that America needs to reform its election system based on the principle of election integrity and the prevention of voter fraud.

- GOP Message 2 (Strong): Republican leaders have argued that America needs to reform its election system based on the principle that only informed citizens should be encouraged to vote.

- GOP Message 3 (Extreme): Republican leaders have argued that America needs to reform its election system based on the principle that only citizens who can speak and read English should be able to vote.

Democratic messages:

- Dem Message 1 (Moderate): Democratic leaders have argued that election reform should be focused on expanding access to the ballot box.

- Dem Message 2 (Strong): Democratic leaders have argued that election reform should be focused on encouraging as many people as possible to vote. 
- Dem Message 3 (Extreme): Democratic leaders have argued that election reform should be focused on expanding voting rights to all U.S. permanent residents, including non-citizens and people in prison for felonies.

This analysis uses OLS models to estimate the effect of the treatments on respondents' prioritization of each principle. The models are run separately on Democrats and Republicans, as the effect of interest is the impact of messaging from one party's elites on people who identify with that party.

The dependent variables are questions asking respondents to choose which of six principles related to election reform they consider most important, one relating to each message. After they choose the first principle, respondents are asked to choose which of the remaining principles is most important, and so on until they choose between their two least preferred principles. When answering this type of question about political principles, respondents tend to make consistent and transitive choices, suggesting it is a valid way to measure principle structures (Jacoby 2011). A respondent's prioritization of principles related to election rules is operationalized by giving each respondent a score from 0 to 1 for each principle. Ranking a principle first yields a score of one and ranking a principle last yields a score of 0 .

The independent variable of interest is a four-category variable indicating which treatment message partisans received from their own party, or whether they were in the control group. This analysis uses the same set of control variables as Study 2: support for multi-party democracy, negative partisanship, age, gender, and race.

\section{Results}

Table 2 below shows the percentage of respondents choosing each principle first. As intended, the most moderate principles were the most likely to be chosen overall, and the most extreme 
principles were the least likely to be chosen. Ensuring voter access and preventing voter fraud were the most popular principles in the full sample. Universal resident voting was the least popular liberal principle, and English-only voting was the least popular conservative principle. Also as intended, Democrats were more likely to select the liberal principles, while Republicans were more likely to select the conservative principles. However, it is worth noting that Democrats were more likely to select the moderate conservative principle than the extreme liberal principle, and the converse was true for Republicans.

Table 2: Percentage of respondents choosing each principle as most important across the full sample.

\begin{tabular}{llll}
\hline Principle & All & Democrats & Republicans \\
\hline Voter Access & $23 \%$ & $29 \%$ & $15 \%$ \\
Encouraging Voting & $20 \%$ & $24 \%$ & $16 \%$ \\
Universal Voting & $13 \%$ & $15 \%$ & $8 \%$ \\
Voter Fraud & $27 \%$ & $19 \%$ & $37 \%$ \\
Informed Voting & $10 \%$ & $8 \%$ & $11 \%$ \\
English-Only Voting & $8 \%$ & $4 \%$ & $13 \%$ \\
\hline
\end{tabular}

This overall ranking of principles is roughly in line with the findings of a recent Pew survey (Pew Research Center 2018), in which "elections free from tampering" was the most strongly agreed-with priority, followed by "no eligible voters denied vote." Achieving high turnout in elections, which roughly corresponds to the "encouraging voting" principle in this study, was considered important by a smaller majority in the Pew study.

Having established that respondents are generally choosing principles in line with expectations, we can answer whether party elites are able to sway people from their prior principles by endorsing 
certain principles. The results of the models testing this hypothesis are shown in Figure 3 . If the elite manipulation hypothesis is correct, we would expect to see significantly higher rates of endorsing the moderate/strong/extreme principle among partisan groups who saw their party elites endorsing those principles.

There is little support for this hypothesis. For none of the six principles did the treatment have the expected effect of significantly increasing the prioritization level of the principle endorsed by party elites. Republicans who received a message endorsing informed voting or an English-only electorate were somewhat more likely to prioritize that principle, but neither effect was statistically significant. Democrats who received the "encouraging voting" message were marginally significantly less likely to prioritize the voter access principle and Democrats who received the "voter access" message were marginally significantly more likely to prioritize noncitizen voting. Neither of these effects would be evidence of elite cues working as intended.
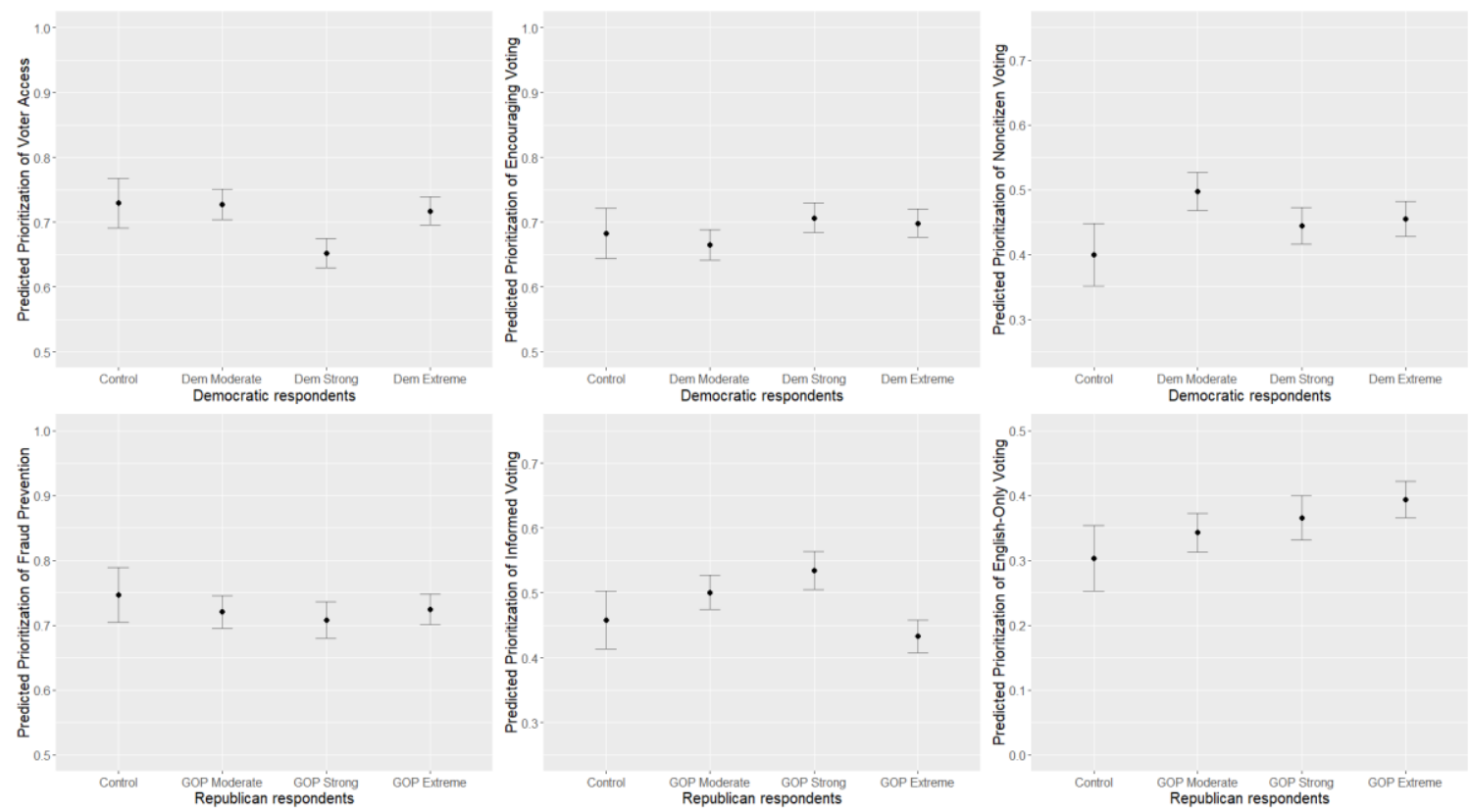

Figure 3: Predicted prioritization of each of six democratic principles by treatment group. Estimates for liberal principles include only Democratic respondents, estimates for conservative principles include only Republican respondents. 
Given the consistent findings in the elite cue literature that out-party policy endorsements have a bigger effect than in-party policy endorsements, it is also of interest to test the effect of out-party principle endorsement on respondents' principle prioritization. There are two possibilities: does opposing party endorsement of opposing party principles make citizens less likely to endorse those principles, and does opposing party endorsement of extreme principles make them more likely to endorse extreme principles on their own side? The former question is one of cue taking, as it asks whether partisans learning the principles that the opposing party endorses makes them learn that those are not their principles. The latter question asks whether there is a backlash effect to one party endorsing extreme principles. These questions are tested in Figures 4 and 5 below.
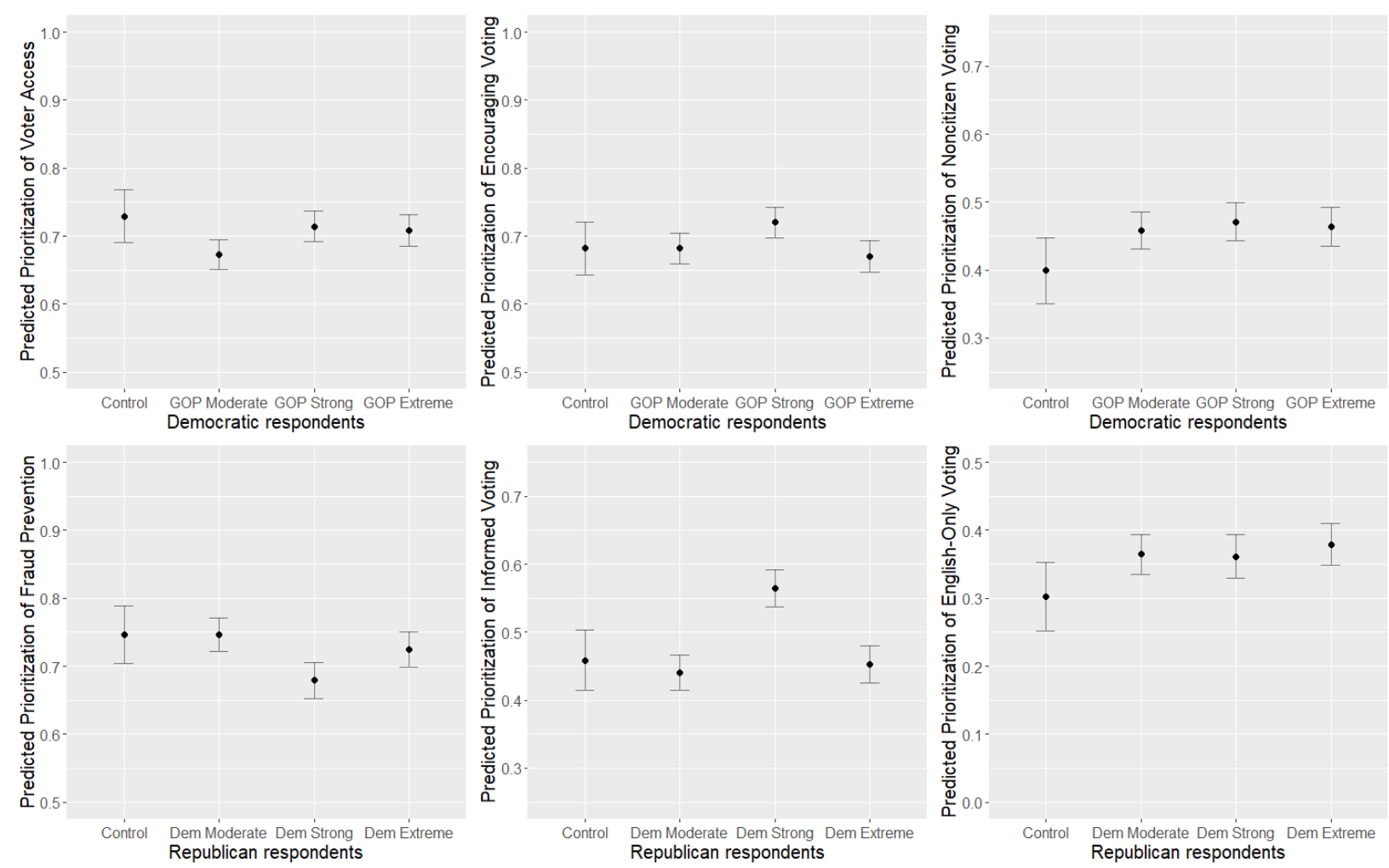

Figure 4: Effect of opposing-party cues on predicted prioritization of same-party principles.

The possibility of a backlash effect is tested in Figure 4. If there were such an effect, we would expect to observe respondents who receive an extreme message from the opposite party be more likely to endorse an extreme principle themselves. Thus, we are most interested in the effect of the 
treatments on Democrats' prioritization of noncitizen voting and Republicans' prioritization of Englishonly voting. There is no evidence for the backlash effect, as all opposing-party messages had similar and non-significant effects on partisans' endorsement of extreme principles. This model did show a significant positive effect for the Democratic message of encouraging voting on Republicans' prioritization of the informed voting principle.
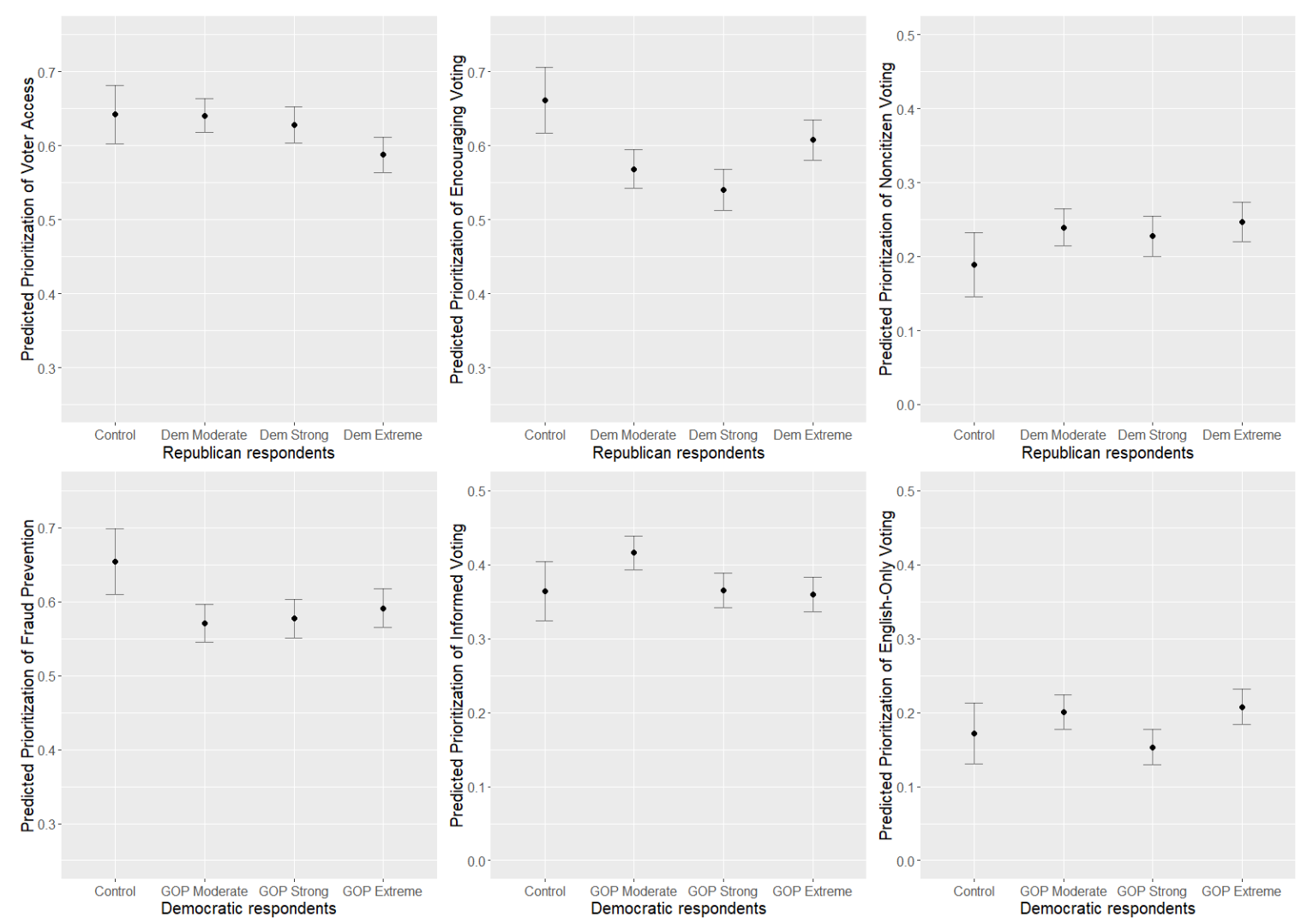

Figure 5: Effect of opposite party endorsements on opposite party principles

Figure 5 tests whether hearing messages from the other party makes people less likely to prioritize the principles endorsed in those messages. There is somewhat more evidence for this hypothesis. Republicans receiving a Democratic endorsement of encouraging voting were significantly less likely to endorse that principle. Democrats receiving a Republican endorsement of preventing voter fraud were marginally significantly less likely to endorse that principle. Overall, however, this remains weak evidence for the ability of parties to influence democratic principles, even among out-partisans. 


\section{Discussion}

This paper explores the boundaries of elites' ability to influence public opinion on election rules. It finds that partisan interest alone is not sufficient to move opinion, as partisans who learn that their party elites are implementing election rules for partisan benefit are less, not more, likely to support those rules. This result helps explain why party elites typically couch their policy positions on election rules in terms of democratic principles, regardless of whether the elites are motivated by partisanship.

While the rhetorical use of democratic principles may be necessary, I also find that elites have a wide latitude of which principles they can use to justify a given policy. The principle-based rationalizations that party leaders use does not appear to make a difference in the effect of their endorsement. Both applicable and inapplicable principles can be effectively used to influence opinion. Pure partisan interest absent elite endorsement does not significantly move public opinion, but the combination of information about partisan interest and elite cues does have a significant effect. This result paints citizens as easily influenced by party elites.

That said, citizens are resistant to attempts by elites to directly influence their principles. Seeing an endorsement of a democratic fairness principle by their party leaders does not cause partisans to be more likely to prioritize that principle. Of particular importance for those worried about the public's willingness to go along with electoral manipulation, elite endorsement of extreme principles does not significantly increase citizens' willingness to endorse those extreme principles. Citizens seem to have deeply-held principles that are not easily swayed by elite cues.

The ability of party elites to influence public opinion on designing systems for running elections appears to be a conditional one. In scenarios in which citizens are asked to make a choice about a lowsalience voting policy change, they are easily influenced by most forms of elite cues that use principlebased justifications. When it comes to fundamental democratic principles, however, politicians have less ability to shape opinion. 


\section{References}

Abramowitz, Alan I., and Steven Webster. 2016. "The Rise of Negative Partisanship and the Nationalization of U.S. Elections in the 21st Century." Electoral Studies 41: 12-22.

Aldrich, John, Jason Reifler, and Michael C. Munger. 2014. "Sophisticated and Myopic? Citizen Preferences for Electoral College Reform." Public Choice 158(3-4): 541-58.

Althaus, Scott L., and Young Mie Kim. 2006. “Priming Effects in Complex Information Environments: Reassessing the Impact of News Discourse on Presidential Approval." Journal of Politics 68(4): 96076.

Beaulieu, Emily. 2014. “From Voter ID to Party ID: How Political Parties Affect Perceptions of Election Fraud in the U.S." Electoral Studies 35: 24-32.

Besley, Timothy, and Torsten Persson. 2019. "Democratic Values and Institutions." American Economic Review: Insights.

Biggers, Daniel R. 2018. “Does Partisan Self-Interest Dictate Support for Election Reform? Experimental Evidence on the Willingness of Citizens to Alter the Costs of Voting for Electoral Gain." Political Behavior 41(4): 1025-46.

Binder, Sarah A. 2006. "Parties and Institutional Choice Revisited." Legislative Studies Quarterly 31(4): 513-32.

Boix, Carles. 1999. "Setting the Rules of the Game: The Choice of Electoral Systems in Advanced Democracies." American Political Science Review 93: 609-24.

Bullock, John G. 2011. "Elite Influence on Public Opinion in an Informed Electorate." American Political Science Review 105(3): 496-515. 
Caldeira, Gregory A., and James L. Gibson. 1992. "The Etiology of Public Support for the Supreme Court." American Journal of Political Science.

Carey, John M. et al. 2018. Party, Policy, Democracy and Candidate Choice in U.S. Elections. http://brightlinewatch.org/us-elections/.

Chong, Dennis, and James N. Druckman. 2007. "Framing Public Opinion in Competitive Democracies." American Political Science Review 101(4): 637-55.

Ciuk, David J., Robert N. Lupton, and Judd R. Thornton. 2018. "Values Voters: The Conditional Effect of Income on the Relationship Between Core Values and Political Attitudes and Behavior." Political Psychology 39(4): 869-88.

DeSilver, Drew. 2016. "U.S. Electoral System Ranks High - but Not Highest - in Global Comparisons." Pew Research Center.

Ditto, Peter H. et al. 2019. “At Least Bias Is Bipartisan: A Meta-Analytic Comparison of Partisan Bias in Liberals and Conservatives." Perspectives on Psychological Science 14(2): 273-91.

Druckman, James N., Erik Peterson, and Rune Slothuus. 2013. “How Elite Partisan Polarization Affects Public Opinion Formation." American Political Science Review 107(01): 57-79.

Drutman, Lee. 2020. Breaking the Two-Party Doom Loop: The Case for Multiparty Democracy in America. Oxford University Press.

Feldman, Stanley. 1988. "Structure and Consistency in Public Opinion: The Role of Core Beliefs and Values." American Journal of Political Science 32(2): 416-40.

Foa, Roberto Stefan, and Yascha Mounk. 2016. "The Danger of Deconsolidation: The Democratic Disconnect." Journal of Democracy 22(3). 
Gibson, James L., and Gregory A. Caldeira. 2009. Citizens, Courts, and Confirmations: Positivity Theory and the Judgments of the American People. Princeton University Press.

Gibson, James L., and Michael J. Nelson. 2015. “Is the U.S. Supreme Court's Legitimacy Grounded in Performance Satisfaction and Ideology?" American Journal of Political Science 59(1): 162-74.

Goren, Paul. 2005. "Party Identification and Core Political Values." American Journal of Political Science 49(4): 881-96.

Goren, Paul, Christopher M. Federico, and Miki Caul Kittilson. 2009. "Source Cues, Partisan Identities, and Political Value Expression." American Journal of Political Science 53(4): 805-20.

Graham, Matthew H., and Milan W. Svolik. 2020. “Democracy in America? Partisanship, Polarization, and the Robustness of Support for Democracy in the United States." American Political Science Review.

Hersh, Eitan D. 2015. Hacking the Electorate: How Campaigns Perceive Voters. Cambridge University Press.

Higgins, E Tory. 1996. "Knowledge Activation: Accessibility, Applicability, and Salience." Social psychology: Handbook of basic principles.

Jacoby, William G. 2011. “Measuring Value Choices: Are Rank Orders Valid Indicators?” In Midwest Political Science Association, https://robobees.seas.harvard.edu/files/cces/files/jacoby_measuring_value_choices-1.pdf.

Kane, John V. 2017. “Why Can't We Agree on Id? Partisanship, Perceptions of Fraud, and Public Support for Voter Identification Laws." Public Opinion Quarterly 81(4): 943-55.

Karp, Jeffrey A., and Caroline J. Tolbert. 2010. “Polls and Elections: Support for Nationalizing Presidential 
Elections." Presidential Studies Quarterly 40(4): 771-93.

Lenz, Gabriel S. 2012. Follow the Leader? How Voters Respond to Politicians' Policies and Performance. University of Chicago Press.

Levitsky, Steven, and Daniel Ziblatt. 2018. How Democracies Die. Crown.

Levitt, Justin. 2014. "A Comprehensive Investigation of Voter Impersonation Finds 31 Credible Incidents out of One Billion Ballots Cast." The Washington Post. https://www.washingtonpost.com/news/wonk/wp/2014/08/06/a-comprehensive-investigationof-voter-impersonation-finds-31-credible-incidents-out-of-one-billion-ballots-cast/.

Lind, E. Allan, and Tom R. Tyler. 1988. The Social Psychology of Procedural Justice. New York and London: Plenum Press.

McCann, James A. 1997. "Electoral Choices and Core Value Change: The 1992 Presidential Campaign." American Journal of Political Science 41(2): 564-83.

McCarthy, Devin. 2019. "Partisanship Against Principle in Public Opinion on Same-Day Registration." Public Opinion Quarterly 83(3): 568-83.

- - 2020. The Limits of Partisanship in Citizen Preferences on Redistricting. https://devinhmccarthy.files.wordpress.com/2019/11/redistricting-opinion_11.5.pdf.

McConnell, Mitch. 2019. "Behold the Democrat Politician Protection Act." The Washington Post. https://www.washingtonpost.com/opinions/call-hr-1-what-it-is-the-democrat-politicianprotection-act/2019/01/17/dcc957be-19cb-11e9-9ebf-c5fed1b7a081_story.html.

Nelson, Thomas E., Zoe M. Oxley, and Rosalee A. Clawson. 1997. "Toward a Psychology of Framing Effects." Political Behavior 19(3): 221-46. 
Nicholson, Stephen P. 2011. "Dominating Cues and the Limits of Elite Influence." Journal of Politics.

--_. 2012. "Polarizing Cues." American Journal of Political Science 56(1): 52-66.

Norris, Pippa. 2017. "Is Western Democracy Backsliding? Diagnosing the Risks." Journal of Democracy 28(2).

Norris, Pippa, Holly Ann Garnett, and Max Grömping. 2020. "The Paranoid Style of American Elections: Explaining Perceptions of Electoral Integrity in an Age of Populism." Journal of Elections, Public Opinion and Parties 30(1).

Pew. 2018. The Public, The Political System and American Democracy. https://www.peoplepress.org/2018/04/26/the-public-the-political-system-and-american-democracy/.

Riker, William H. 1982. Liberalism Against Populism: A Confrontation Between the Theory of Democracy and the Theory of Social Choice. San Francisco: W.H. Freeman.

Schwartz, Shalom H. 1994. "Are There Universal Aspects in the Structure and Contents of Human Values?" Journal of Social Issues 50(4): 19-45.

Sunshine, Jason, and Tom R. Tyler. 2003. "The Role of Procedural Justice and Legitimacy in Shaping Public Support for Policing." Law and Society Review 37(3): 513-48.

The Health of American Democracy: Comparing Perceptions of Experts and the American Public. 2017. http://brightlinewatch.org/blw-survey-wave3/.

Tolbert, Caroline J., Daniel A. Smith, and John C. Green. 2009. "Strategic Voting and Legislative Redistricting Reform: District and Statewide Representational Winners and Losers." Political Research Quarterly 62(1): 92-109.

Tyler, Tom R. 2013. Achieving Peaceful Regime Change: Why Do Losers Consent? 
https://law.yale.edu/sites/default/files/documents/pdf/sela/SELA13_Tyler_CV_Eng_20130321.pdf.

Ura, Alexa. 2019. “'Someone Did Not Do Their Due Diligence': How an Attempt to Review Texas' Voter Rolls Turned into a Debacle." The Texas Tribune. https://www.texastribune.org/2019/02/01/texascitizenship-voter-roll-review-how-it-turned-boondoggle/.

Wines, Michael. 2016. "Some Republicans Acknowledge Leveraging Voter ID Laws for Political Gain." The New York Times. https://www.nytimes.com/2016/09/17/us/some-republicans-acknowledgeleveraging-voter-id-laws-for-political-gain.html.

Woon, Jonathan. 2007. “Direct Democracy and the Selection of Representative Institutions: Voter Support for Apportionment Initiatives, 1924-62." State Politics and Policy Quarterly 7(2): 167-86.

Yeyati, Eduardo Levy, Lorena Moscovich, and Constanza Abuin. 2020. "Leader over Policy? The Scope of Elite Influence on Policy Preferences." Political Communication.

Zaller, John R, and Stanley Feldman. 1992. "A Simple Model of the Survey Response: Answering Questions versus Revealing Preferences." American Journal of Political Science 36(3): 579-616. 


\section{Appendix A: Sample Composition}

Table A1: Demographic characteristics across each treatment group in Study 1a, for the policies of making Election Day a holiday (EDH) and vote-by-mail (VBM).

\begin{tabular}{lccccccccccc}
\hline \multicolumn{1}{c}{ Policy } & \multicolumn{4}{c}{ Election Day Holiday } & \multicolumn{9}{c}{ Vote-by-Mail } \\
\hline & Control & $\begin{array}{l}\text { Party } \\
\text { Info }\end{array}$ & Bureau & Fraud & $\begin{array}{l}\text { Dem } \\
\text { Benefit }\end{array}$ & Control & $\begin{array}{l}\text { Party } \\
\text { Info }\end{array}$ & Bureau & Fraud & $\begin{array}{l}\text { Dem } \\
\text { Benefit }\end{array}$ \\
\hline Female & 0.46 & 0.49 & 0.54 & 0.53 & 0.51 & 0.49 & 0.55 & 0.48 & 0.47 & 0.54 \\
Black & 0.15 & 0.11 & 0.11 & 0.1 & 0.11 & 0.14 & 0.1 & 0.12 & 0.12 & 0.13 \\
Hispanic & 0.07 & 0.09 & 0.09 & 0.1 & 0.08 & 0.11 & 0.08 & 0.11 & 0.07 & 0.1 \\
Democrat & 0.51 & 0.48 & 0.5 & 0.48 & 0.52 & 0.49 & 0.48 & 0.45 & 0.5 & 0.47 \\
Republican & 0.35 & 0.39 & 0.36 & 0.38 & 0.36 & 0.28 & 0.34 & 0.4 & 0.33 & 0.41 \\
$\begin{array}{l}\text { Multi-Party } \\
\text { Democracy }\end{array}$ & 2.55 & 2.41 & 2.38 & 2.6 & 2.56 & 2.68 & 2.62 & 2.48 & 2.6 & 2.63 \\
\hline
\end{tabular}

Table A2: Demographic characteristics across each treatment group in Study 1b.

\begin{tabular}{llll}
\hline & Control & Endorse Only & Principle \\
\hline Female & 0.49 & 0.54 & 0.47 \\
Black & 0.13 & 0.11 & 0.14 \\
Hispanic & 0.09 & 0.10 & 0.04 \\
Republican & 0.51 & 0.46 & 0.45 \\
Democrat & 0.33 & 0.38 & 0.41 \\
Multi-Party System & 2.62 & 2.56 & 2.62 \\
\hline
\end{tabular}


Table A3: Demographic characteristics across each treatment group in Study 2.

\begin{tabular}{lrrr}
\hline & Control & Auto Reg First & Voter ID First \\
\hline Female & 0.59 & 0.54 & 0.63 \\
Black & 0.08 & 0.09 & 0.10 \\
Hispanic & 0.10 & 0.10 & 0.09 \\
Republican & 0.50 & & 0.43 \\
Democrat & 0.34 & 0.46 & 0.42 \\
Education (1-6) & 3.65 & 0.39 & 3.53 \\
& & 3.60 & \\
\hline
\end{tabular}

Table A4: Demographic characteristics across each treatment group in Study 3.

\begin{tabular}{lllllllll}
\hline & \multicolumn{4}{c}{ Democratic Messages } & \multicolumn{3}{c}{ Republican Messages } \\
\hline Female & Control & Moderate & Strong & Extreme & Moderate & Strong & Extreme \\
\hline Black & 0.50 & 0.57 & 0.56 & 0.55 & 0.59 & 0.59 & 0.49 \\
Hispanic & 0.11 & 0.12 & 0.12 & 0.12 & 0.12 & 0.12 & 0.12 \\
Democrat & 0.06 & 0.08 & 0.08 & 0.07 & 0.07 & 0.09 & 0.07 \\
$\begin{array}{l}\text { Republican } \\
\begin{array}{l}\text { Multi-Party } \\
\text { Democracy }\end{array}\end{array}$ & 0.44 & 0.43 & 0.47 & 0.45 & 0.46 & 0.47 & 0.43 \\
\hline
\end{tabular}

